\title{
Work Environment Factors and Their Influence on Urinary Chromium Levels in Informal Electroplating Workers
}

\author{
Yuliani Setyaningsih ${ }^{1, *}$, Adi Heru Husodo ${ }^{2}$, and Indwiani Astuti ${ }^{2}$ \\ ${ }^{1}$ Public Health Faculty, Diponegoro University, Semarang - Indonesia \\ ${ }^{2}$ Medical Faculty, Univers itas Gadjah Mada, Yogyakarta - Indonesia
}

\begin{abstract}
One of the informal sector which absorbs labor was electroplating business. This sector uses chromium as coating material because it was strong, corrosion resistant and strong. Nonetheless hexava lent chromium is highly toxic if inhaled, swallowed and contact with skin. Poor hygiene, the lack of work environment factors and sanitation conditions can increase the levels of chromium in the body. This aimed of this study was to analyze the association between work environment factors and levels of urinary chromium in informal electroplating worker. A Purposive study was conducted in Tegal Central Java. The research subjects were 66 male workers. Chi Square analysis was used to establish an association between work environment factors and level of urinary chromium. There is a relationship between heat stress and wind direction to the chromium levels in urine $(\mathrm{p}<0.05)$, but there is no relationship between humidity and levels of chromium in the urine $(p>0.05)$. This explains that work environment factors can increase chromium levels in the urine of informal electroplating workers.
\end{abstract}

\section{Introduction}

Chromium is commonly used in various industrial processes such as stainless steel production, welding, tannery and metal coating. Chromium is one of the heavy metals that are often used as a metal coating because of its anti-corrosive properties and can beautify the surface into a shiny white [1-2]. Clinical and laboratory evidence suggests that chromium (VI) is responsible for most poisoning events. Chromium (VI) is highly toxic by inhalation, in contact with skin and ingested through consumption of foods and beverages containing chromium (VI). It can cause lung cancer, nasal irritation, nasal ulcers, hypersensitivity reactions such as contact dermatitis and asthma [3-4].

Inhalation routes are the main entrance and exposure of workers. Workers can inhale chromium in the form of gas, dust or particles while working around the electroplating tub. Particles with a diameter size less than $5 \mu$ can reach the alveoli and dissolve into the bloodstream. Chromium is reduced by macrophages in the bronchial branches and pulmonary parenchymal cells [5-6]. The respiratory tract is the main target of $\mathrm{Cr}(\mathrm{VI})$ toxicity and is associated with chronic and acute exposure [4,7]. Exposure to Cr (VI) in the body mainly through inhalation of aerosols can cause health problems in the respiratory tract, carcinogenic, liver, kidney and immune system disruption. Several in-vitro studies indicate that $\mathrm{Cr}$ (III) concentrations in cells can cause DNA damage [8].

The work environment can be the determinant variable of air pollution dynamics such as wind direction and speed, humidity and working climate. An increased temperature can increase the reaction rate of a chemical [9]. High levels of chromium levels in the urine can be used as an indicator of high chromium exposure indoors [10].

From the preliminary survey, it is known that some workers work in a work area that integrates with residence. Limited ventilation and poor sanitation hygiene can increase air pollutant levels and harm workers' health conditions. Therefore the researchers wanted to examine the relationship between environmental factors with chromium levels in the urine of informal metal coating workers.

\section{Research method}

This research is observational with cross sectional design. The study was conducted on an informal electroplating worker in Tegal, Central Java. The subjects consisted of 66 male workers with criteria already working for 1 year and exposed by chromium. Chromium in the urine of the worker can be used as an indicator of the amount of chromium that enters the body. A total of $10 \mathrm{~mL}$ of urine was collected from the respondents after working for 4 hours. Level or urinary chromium was measured by flameless atomic absorption spectrophotometer (AAS) with a graphite furnace (GF3000) and auto-sampler (PAL-3000) [10]. Working climate and humidity are measured using the heat stress area of the Questemp 34 brand monitors with reference to the standard SNI No. 16-7061-2004. Wind speed is measured by an Anemometer. Data were analyzed by

*Corresponding author: joeliani kesja undip@yahoo.com 
using bivariate analysis covering environmental and chromium levels in urine by using Chi-Square

\section{Result and analysis}

A total of 66 respondents were male. All of them do not use personal protective equipment when working. Age ranges from 17-56 years and has a working period of 1 40 years.

\subsection{Work Environment Factor}

Work environment factors are assessed by measuring the working climate, humidity and wind direction in the metal coating production site. The heat stress measured at 12 workplaces ranged from 27.8 o $\mathrm{C}-29.5{ }^{\circ} \mathrm{C}$. According to Ministry of Manpower \& Transmigration Regulation No. Per.13 / MEN / X / 2011, the ISBB threshold is permitted for $75 \%-100 \%$ working hours arrangement with moderate work, a permissible working climate is $280 \mathrm{C}$. Humidity measured In 12 workplaces ranged from $73 \%-87 \%$. The humidity allowed in the work space is between $65-85 \%$. As for the wind direction is divided into work exposed to the wind direction parallel and opposite to the wind direction. Workers exposed by environmental factors can be seen in table 1.

Table 1. Frequency Distribution of Metal Coating Workers exposed to Environmental Factors in Talang Subdistrict, Tegal Regency, 2014

\begin{tabular}{|c|c|c|c|}
\hline No. & Respondent exposed & $\mathbf{N}$ & $\%$ \\
\hline 1. & \begin{aligned} & \multicolumn{3}{l}{ Heat stress } \\
& a. Non - appropriate \\
& ISBB \\
& b. $\begin{array}{l}\text { Appropriate } \\
\left(28^{0} \mathrm{C}\right)\end{array} \\
&$ ISBB \end{aligned} & $\begin{array}{l}40 \\
26\end{array}$ & $\begin{array}{l}60.6 \\
39.4\end{array}$ \\
\hline 2. & $\begin{array}{l}\text { Humidity } \\
\begin{aligned} \text { a. Non - appropriate } \\
\text { b. Appropriate }(65-85 \\
\\
\%)\end{aligned}\end{array}$ & $\begin{array}{l}32 \\
34\end{array}$ & $\begin{array}{l}48.5 \\
51.5\end{array}$ \\
\hline 3 & $\begin{array}{l}\text { Wind Direction } \\
\begin{aligned} \text { a. } & \text { Opposites } \\
\text { b. } & \text { Linear }\end{aligned}\end{array}$ & $\begin{array}{l}46 \\
20\end{array}$ & $\begin{array}{l}69.7 \\
30.3\end{array}$ \\
\hline
\end{tabular}

Metal coating workers work in an environment with an unsuitable heat stress ISBB of $60.6 \%$. In addition, there are $48.5 \%$ of workers in a production room with unsuitable humidity for the workplace. A total of $69.7 \%$ of workers were exposed to chromium vapor directly because while in the production room working opposite to the wind direction. The longer workers work, the risk of exposure to sharp-smelling chemicals is greater, given that workers do not use personal protective equipment such as masks and gloves [11]. The Environmental Protection Agency (EPA) and the International Agency for Research on Cancer (IARC) indicate that $\mathrm{Cr}$ (VI) is inhaled otherwise carcinogens in humans and latent danger occurs for 20 years and the shortest duration of exposure is 2 years [12].

\subsection{Urinary examination in electroplating workers}

Worker's urine was taken after work for 4 hours and before lunch break of $+5 \mathrm{ml}$. The urine sample was then collected in a polypropylene container, and urine chromium $(5 \mathrm{ml})$ was examined. The results of urine examination of metal coating workers can be seen in Table 2.

Table 2. Frequency distribution of Chromium content, MDA levels and 8-OHdG levels of Metal Coating Workers in Talang Sub-district, Tegal Regency, 2014

\begin{tabular}{|c|c|c|}
\hline Variable & N & \% \\
\hline Chromium Levels & & \\
a. $\geq 11.77 \mu \mathrm{g} / \mathrm{L}$ & 32 & 48.5 \\
b. $\quad<11.77 \mu \mathrm{g} / \mathrm{L}$ & 34 & 51.5 \\
\hline
\end{tabular}

As many as $51.5 \%$ of workers with chromium levels were less than median $(11.7 \mu \mathrm{g} / \mathrm{L})$. Chromium is actually a natural heavy metal and is an essential micronutrient to support insulin work. However, chromium is highly toxic by inhalation, in contact with skin and swallowed [3-4]. Chromium levels in the worker urine in this study had a minimum value of 2.811 $\mu \mathrm{g} / \mathrm{L}$ and a maximum value of $145.340 \mu \mathrm{g} / \mathrm{L}$. This value is higher than the normal range for chromium urine in humans is between $0.1 \mu \mathrm{g} / \mathrm{L}-0.5 \mu \mathrm{g} / \mathrm{L}$ while the threshold value of chromium in urine $0.05 \mu \mathrm{g} / \mathrm{L}$ [13]. Chromium in urine shows absorption for 1-2 Days before the examination [4].

\subsection{Complaints pain}

Table 3.Types of complaints Pain suffered by Metal Coating Workers in Talang Sub-district, Tegal Regency, 2014.

\begin{tabular}{|l|l|c|r|}
\hline No & Complaints Pain & Total & \% \\
\hline 1. & Itchy & 8 & 12.12 \\
\hline 2. & Cough & 2 & 3.03 \\
\hline 3. & Shortness of breath & 3 & 4.55 \\
\hline 4. & Musculoskeletal disorder & 7 & 10.60 \\
\hline 5. & Itchy and Cough & 3 & 4.55 \\
\hline 6. & $\begin{array}{l}\text { Itchy, Cough and shortness of } \\
\text { breath }\end{array}$ & 2 & 3.03 \\
\hline 7. & $\begin{array}{l}\text { Itchy, Cough and } \\
\text { Musculoskeletal disorder }\end{array}$ & 2 & 3.03 \\
\hline 8. & No complaints & 39 & 59.09 \\
\hline
\end{tabular}

Table 3 shows how many complaints of workers such as itching, coughing, and shortness of breath and musculoskeletal complaints. There are $10.58 \%$ of metal coating workers who experience 2 or more complaints of illness due to their work while $59.09 \%$ admitted to having no complaints during their work.

Of workers who feel sick $45.5 \%$ of workers choose to buy medicine in stall when feeling pain, $25.8 \%$ choose to Community Health Center - puskesmas and the rest choose not to cure. Informal sector workers have a higher risk in relation to health problems suffered by the work [11]. Zeins says that high chromium content can 
affect respiratory symptoms and increased bronchial asthma [14].

All workers do not use PPE. To prevent inhaled chemicals and skin contacts the worker should improve personal hygiene such as regular hand washing and showering after work hours. General ventilation can be used to drain the air into the room so that the levels of harmful chemicals become lower in the air. In addition, it can also use local exhauster, the installation that sucks air in a certain place through the canopy for dangerous chemicals to be flown out of the workplace space [15]. Workers should use PPE as the last preventive measure of exposure to chemicals. PPE is not a substitute for hazard control either engineering or administrative engineering but if hazard control is not possible then APD can be used wherever danger can be absorbed, swallowed or inhaled [16].

\subsection{Statistical test}

The variables of working environment factors measured include working climate, humidity and wind direction. Table 4 shows the test results of the relationship between environmental factor variables and chromium levels in the urine of metal coating workers.

Table 4. Test Result Relation between work capacity variable with chromium content in urine Metal Coating Worker, Talang Sub-district, Tegal Regency, 2014

\begin{tabular}{|l|l|c|c|c|}
\hline No. & $\begin{array}{c}\text { Variable of } \\
\text { environment } \\
\text { factors }\end{array}$ & $\boldsymbol{p}$ & OR & $\mathbf{9 5 \%}$ CI \\
\hline 1. & $\begin{array}{l}\text { Heat stress with } \\
\text { chromium level } \\
\text { (ISBB) }\end{array}$ & $\mathbf{0 . 0 3 8}$ & $\mathbf{3 . 3 7 5}$ & $\mathbf{1 . 1 8 6 - 9 . 6 0 4}$ \\
\hline 2. & $\begin{array}{l}\text { Humidity with } \\
\text { chromium level }\end{array}$ & 0.617 & 0.691 & $0.262-1.824$ \\
\hline 3. & $\begin{array}{l}\text { Wind direction } \\
\text { with chromium } \\
\text { level }\end{array}$ & $\mathbf{0 . 0 0 5}$ & $\mathbf{6 . 2 2 2}$ & $\mathbf{1 . 7 9 1 - 2 1 . 6 1 8}$ \\
\hline
\end{tabular}

The results of statistical tests show that the working climate and wind direction are related to chromium levels in the worker's urine $(\mathrm{p}<0.05)$. Only humidity is not associated with chromium levels in the worker's urine $(p>0.05)$. Workers in climatic working environments not in accordance with ISBB $(>280 \mathrm{C})$ have a chance of 3.37 times having chromium levels greater than $11.77 \mu \mathrm{g} / \mathrm{L}$ in their urine compared with workers working in a heat stress-conditioned room in accordance with ISBB (OR = 3,375 ). In addition, workers working in the opposite wind direction of the electroplating tub have a chance of 6.22 times having chromium levels of more than $11.77 \mu \mathrm{g} / \mathrm{L}$ in their urine compared to workers working on the parallel wind direction of the electroplating bath $(\mathrm{OR}=6.222)$.

The results of statistical tests show that the working climate and wind direction are related to chromium levels in the worker's urine $(p<0.05)$. Only humidity is not associated with chromium levels in the worker's urine $(p>0.05)$. Workers in climatic working environments not in accordance with ISBB (>28 0 C) have a chance of 3.37 times having chromium levels greater than $11.77 \mu \mathrm{g} / \mathrm{L}$ in their urine compared with workers working in a heat stress-conditioned room in accordance with ISBB (OR $=3,375$ ). In addition, workers working in the opposite wind direction of the electroplating tub have a chance of 6.22 times having chromium levels of more than $11.77 \mu \mathrm{g} / \mathrm{L}$ in their urine compared to workers working on the parallel wind direction of the electroplating bath $(\mathrm{OR}=6,222)$. The temperature and chemical concentrations of the electrochemical tub are regulated during the metal coating process. When the tub starts to be heated, smog will appear and exposure to the worker will increase [13]. Guillemin and Berode in Greenberg [13] also stated that the concentration of chromium content in the air is higher in the hard plating process and the chromium levels found in urine are also higher. Hard plating uses higher temperatures and more chemicals in the electroplating tub than with bright plating.

The worker as a dye is closer to the electroplating tub than the non-dyeer. Metal coating workers are exposed by particle and hexavalent $\mathrm{Cr}$ fog resulting from the electrolysis process occurring in the electroplating basin. These particles and fogs occur as a result of bursts on the liquid surfaces in the electroplating basins coming from oxygen bubbles and hydrogen out of the electrodes during the coating process [5].

In addition, the multivariate test using smart PLS proved that there is a relationship between environmental factors to chromium levels in urine. Environmental factor variables are formed by wind direction indicators and heat stress (ISBB). The overheated heat stress will increase the process of vaporization of $\mathrm{Cr}$ in the tub. It is still exacerbated by a working position opposite to the wind direction; consequently, workers will be exposed to greater chromium during inhalation [4]. Mukono [17] states that increased temperatures plus the presence of sunlight, including the occurrence of reactions of 2 or more secondary pollutants, may cause increased effects of toxic substances in the air. Secondary pollutants have unstable physical and chemical properties so it is very easy to react and change their chemical makeup in the presence of other chemicals in the air as well as in the body. Husaini [18] states that a hot climate or working temperature will greatly affect the rate of chemical reactions in the air especially in the worker's body where each work is always exposed.

\section{Conclusions}

Heat stress and wind direction are related to chromium levels in the urine of informal electroplating workers while the moisture is not related to chromium levels in the urine of informal electroplating workers. The presence of chromium in urine can be used as an indicator of high chromium exposure in the workplace.

\section{Acknowledgements}

The authors would like to thank to the Ministry of Research and Technology and Higher Education of the 
Republic of Indonesia, which has provided the doctoral scholarship program; Biochemistry and Parasitological Laboratory of Medical Faculty, Universitas Gadjah Mada in Yogyakarta; and BBTKLPP for analyzing urinary chromium.

\section{References}

1. A. Gambelunghe, R. Piccinini R, M. Ambrogi, M. Villarini , M. Moretti , C. Marchetti , G. Abbritti, G. Muzi. Toxicology 188, 187-195. (2003)

2. Caglieri, Andrea, G. Matteo, A. Olga, A. Roberta, V. Maria, C. Massimo, A. Pietro, M. Antonio, Environmental Health Perpectives. Vol 114. No 4. (2004)

3. R. Shrivastava, R.K. Upreti, P.K. Seth, U.C. Chaturvedi, FEMS Immunology and Medical Microbiology, 34 , 1-7, (2002.)

4. Agency for Toxic Substances and Disease Registry (ATSDR). Toxicological Profile for Chromium. (2012)

5. Y. Hedberg, Johanna Gustafsson, Hanna L Karlsson, Lennart Möller, Inger Odnevall Wallinder. Particle and Fibre Toxicol.7:23. (2010)

6. A.P. Das, S. Singh, J. Occup Environ Med . JanApr; 15(1): 6-13 (2011)

7. De Flora S, Carcinogenesis 21:533-541 (2000)

8. D.A. Esmond, J.T. Macgregor, R.S. Slesinski, Trivalent, Crit Rev. Toxicol, 38 :173-190 (2008)
9. UF. Achmadi, Manajemen Penyakit Berbasis Wilayah. Edisi revisi. (2014)

10. Y. Setyaningsih. Adi Heru Husodo. Indriani Astuti. Detection Urinary8-Hidroxydeoxyguanosine (8OHdG) Levels as a Biomarker of Axydative DNA Damage Among Home Industry Workers Exposed to Chromium. Vol 23. 290-296. (2015)

11. Anies. Penyakit Akibat Kerja. (2005)

12. V. Kapol, J. Keogh, Case Studies in Environmental Medicine. (1990)

13. Greenberg, I. Michael, J.H. Richard, D.P. Scott, J.M. Gayla, Occupational Industrial and Environmental Toxicology. E 2, (2003)

14. M. Zeins, C.I. Rivard, JL. Malo, D. Gautrin, Is Metal Fume Fever a Determinant of Welding Related Respiratory Symptomps and/or Increased Broncial Responsiveness? 62. 688-694. (2005)

15. Soedirman. Higiene Perusahaan. (2012)

16. Damanik, HL. Adi Heru Husodo. Totok Gunawan. Pramono Adi. Model Pengendalian Kesehatan Tenaga Kerja pada Kegiatan Pengecoran Logam Tradisional Studi Kasus di Kawasan Industri Batur Klaten-Jawa Tengah. Vol 4. 101-198. (2015)

17. HJ. Mukono, Toksikologi Lingkungan. (2005)

18. H. Husaini, N E S., H H. Marsetyawan Adi, Studi Kasus : Koreksi Terhadap Pengukuran Polutan di Udara Unit Perajin Logam dan Dampaknya Terhadap Kesehatan, Buletin Penelitian Kesehatan, Vol 44, No 2 (2016). 